\title{
Izobraževalni management - izobraževanje v gospodarstvu
}

Pred vami je posebna številka revije Andragoška spoznanja. Pripravili smo jo ob prvi slovenski konferenci Izobraževalni management, na kateri bomo na eni odstirali dileme izobraževanja v slovenskem gospodarstvu, na drugi strani pa predstavili uspešne primere upravljanja znanja in skupaj odkrivali, v katero smer ter s kakšno intenziteto se razvija izobraževalni management in kaj moramo storiti, da ga bomo lahko učinkovito spremljali ter uresničevali v praksi.

Morda smo nekoč pričakovali, da nas bosta šola in šolski sistem opremila $\mathrm{z}$ znanjem za vse življenje, vendar smo spoznali, da šola temu ni kos, niti ni to njena najpomembnejša naloga. Njena naloga je predvsem, da nas nauči in motivira za vseživljenjsko učenje. Odgovornosti za neznanje ne moremo več prenašati na druge, odgovornost je na nas samih. Tako kot morajo posamezniki in organizacije sami prevzeti skrb za svoj razvoj, morajo tudi sami poskrbeti za nenehen dotok svežega znanja. V tistih organizacijah, kjer se ukvarjajo predvsem $\mathrm{z}$ inovacijami, pa sta učenje in izobraževanje vir preživetja.

Kadar poslovneži omenjajo visoko vrednost podjetja in ključne zaposlene, ponavadi govorijo o znanju ter strokovnosti, torej o intelektualnem kapitalu in ne več o finančnem kapitalu ali proizvodnih sredstvih. Najpomembnejše premoženje v organizacijah 21. stoletja, poslovnih in neposlovnih, so delavci znanja. Glede na to se tudi v izobraževanje zaposlenih vlaga več, kot se je vlagalo doslej. In ker so podjetja ekonomski sistemi, v njih tudi razmišljajo po ekonomski logiki, torej priča-
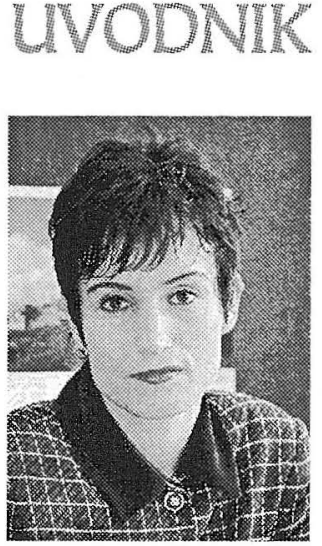

mag. Daniela Brečko kujejo, da se jim bo denar, ki so ga vložili v zaposlene, povrnil Če zaposleni ne bi pripomogli k profitabilnosti in vrednosti podjetja, ne bi bilo ekonomsko smiselno, da bi vanje vlagali, temveč bi bilo bolje vlagati drugam. Celo v neprofitnih organizacijah morajo zaposleni izpolnjevati organizacijske cilje, če želijo preživeti, čeprav ti cilji niso izraženi v denarju.

Silovit razmah in razvoj tehnologije sta omogočila, da so informacije, iz katerih lahko pridobimo znanje, pravzaprav povsod. Včasih jih je bilo premalo in smo jih zavestno iskali, danes pa jih je že preveč in se jim zavestno izogibamo. Zato so pomembnejši selekcioniranje, procesiranje in urejanje teh informacij, da bi se spremenile v znanje in intelektualni kapital. Prav urejanje informacij in pomoč pri njihovem procesiranju pomenita tudi tržno vrednost znanja, ki se dokončno izrazi v izobraževalnem programu in je hkrati tudi didaktično jedro izobraževalnega managementa.

Drugo pomembno vprašanje, ki bi si ga morale zastaviti organizacije, pa je, kako omogočiti dostop do znanja slehernemu zaposlenemu ter zagotoviti transfer znanja med zaposlenimi in tako racionalizirati procese pridobivanja znanja na ravni organizacije ter se čimbolj približati učečemu se podjetju. Trenutno je večina iskanj usmerjenih k e-izobraževanju, ki po najnovejših raziskavah ustreza značilnostim sodobne učeče se organizacije - pomeni neizmeren vir znanja, dostopnost, prihranek časa in nižje stroške.

Ne glede na nove metode, pristope, tehnološke rešitve pa ostaja njihova najpo- 
membnejša naloga usposobiti zaposlene za pridobivanje znanja. Zato najbrž ni naključje, da se je v svetu že pojavil nov poklic, tj. tako imenovani »knowledge manager«, torej upravljalec znanja, ki bo imel zelo pomembno vlogo pri razvoju organizacije. Skrbeti bo moral za to, da se bodo izobraževali prav vsi, zagotoviti transfer znanja, sklepati učne pogodbe in tudi znati izmeriti učinkovitost svojega dela, torej oceniti po veljavnih parametrih rezultate vlaganja $\mathrm{v}$ znanje.

V strokovnih krogih se pogosto postavlja vprašanje, kaj se bo dogajalo $\mathrm{v}$ izobraževalnem managementu med pričakovano recesijo. Sama bi vprašanje postavila drugače. Ali bi do recesije sploh prišlo, če bi izobraževanje vzeli zares, torej kot življenjsko poslanstvo? Če vprašanje zastavimo tako, je odgovor nanj, ali med gospodarsko recesijo vlagati $\mathrm{v}$ izobraževanje več, kot na dlani. Da, in sicer več! Vlaganja $\mathrm{v}$ pravo znanje nikoli ne morejo biti previsoka.

$\mathrm{Na}$ tej konferenci bomo praktiki in teoretiki skupaj reševali dileme, povezane $\mathrm{z}$ izobraževanjem $v$ gospodarstvu, skušali najti metodologijo za ugotavljanje ekonomičnosti vlaganja $v$ izobraževanje, iskali sodobnejše in racionalnejše poti za pridobivanje novega znanja, predstavili praktične modele strategij ter organiziranosti izobraževanja v organizacijah in novosti na slovenskem izobraževalnem trgu.

Ker živimo v učečem se tisočletju, je prav, da ustvarimo tudi možnosti in takšno okolje, $v$ katerem bomo lahko brez ovir zadostili potrebam po izobraževanju. Vesela sem, da so se nam pri teh prizadevanjih pridružili številna slovenska podjetja in organizacije, predstavniki lokalnih skupnosti, političnega življenja in univerz. Z vsakim takšnim korakom bomo napredovali pri uresničevanju načela vseživljenjskega učenja. Vsi, ki ste pripravili prispevke, ste ta korak že naredili. Za to se vam zahvaljujem in vas vabim, da se nam pridružite tudi prihodnje leto. Vsem pa želim čim večji osebni »izkupiček« na konferenci.

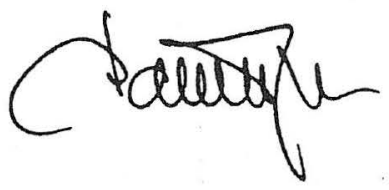

